\title{
PERBANDINGAN PENERAPAN STRATEGI PEMBELAJARAN PENINGKATAN KEMAMPUAN BERPIKIR (SPPKB) DENGAN STRATEGI PEMBELAJARAN EKSPOSITORI (SPE) TERHADAP KEMAMPUAN PENALARAN MATEMATIS PESERTA DIDIK
}

\section{THE COMPARISON OF THE IMPLEMENTATION OF THINKING ABILITY ENHANCEMENT LEARNING STRATEGY (TAELS) AND EXPOSITORY LEARNING STRATEGY (ELS) TOWARDS STUDENTS' MATHEMATICAL REASONING ABILITY}

\author{
Nur Indarwati1), Thamrin Tayeb22), Andi Ulmi Asnita3), Nur Yuliany4), Lisnasari Andi \\ Mattoliang5) \\ 1,2,3,4,5)Fakultas Tarbiyah dan Keguruan Universitas Islam Negeri Alauddin Makassar \\ nurindar575@gmail.com ${ }^{1}$, thamrin.tayeb@uin-alauddin.ac.id ${ }^{2}$,,$\underline{\text { ulmi.asnita@uin-alauddin.ac.id }}{ }^{3}$, \\ nur.yuliany@uin-alauddin.ac.id ${ }^{4}$, lisnasari.mattoliang@uin-alauddin.ac.id ${ }^{5}$ )
}

\begin{abstract}
Abstrak
Penelitian ini bertujuan untuk membandingkan kemampuan penalaran matematis peserta didik kelas VII UPT SMPN 3 Mattirosompe dengan menerapkan Strategi Pembelajaran Peningkatan Kemampuan Berpikir (SPPKB) dan Strategi Pembelajaran Ekspositori (SPE). Jenis penelitian yang digunakan adalah quasi eksperiment dengan desain non equivalent control group. Teknik analisis data yang digunakan adalah analisis statistik deskriptif dan analisis statistik inferensial. Hasil penelitian menunjukkan bahwa kemampuan penalaran matematis peserta didik dengan penerapan SPPKB pada umumnya berada pada kategori sangat tinggi dan kemampuan penalaran matematis peserta didik dengan penerapan SPE pada umumnya berada pada kategori tinggi. Selain itu, terdapat perbedaan kemampuan penalaran matematis peserta didik dengan menerapkan SPPKB dan SPE, dimana hasil kemampuan penalaran matematis peserta didik yang diajar dengan menerapkan SPPKB lebih tinggi dibandingkan dengan kemampuan penalaran matematis peserta didik yang diajar dengan menerapkan SPE di kelas VII UPT SMPN 3 Mattirosompe.
\end{abstract}

Kata Kunci: kemampuan penalaran matematis, strategi pembelajaran peningkatan kemampuan berpikir (SPPKB), strategi pembelajaran ekspositori (SPE)

\begin{abstract}
This study aims to compare the mathematical reasoning abilities of the seventh grade students of UPT SMPN 3 Mattirosompe using thinking ability enhancement learning strategy (TAELS) and Expository Learning Strategies (ELS). This type of research is a quasi experiment with a non equivalent control group design. The data analysis technique used is descriptive statistical analysis and inferential statistical analysis. The results showed that students 'mathematical reasoning abilities with the application of TAELS were generally in the very high category and students' mathematical reasoning abilities with the application of ELS were generally in the high category. Besides, there are differences in students 'mathematical reasoning abilities using TAELS and ELS, where the results of students' mathematical reasoning abilities taught by TAELS are higher than students 'mathematical reasoning abilities taught using SPE in class VII students of UPT SMPN 3 Mattirosompe.
\end{abstract}

Keywords: mathematical reasoning ability, thinking ability enhancement learning strategy (TAELS), expository learning strategy (ELS) 
How to Cite: Indarwati, N., Tayeb, T., Asnita, A. U., Yuliany, N. \& Mattoliang, L. A. (2020). Perbandingan penerapan Strategi Pembelajaran Peningkatan Kemampuan Berpikir (SPPKB) dengan Strategi Pembelajaran Ekspositori (SPE) terhadap kemampuan penalaran matematis peserta didik. Al asma: Journal of Islamic Education, 2(2), 181-188.

\section{PENDAHULUAN}

Pembelajaran matematika sebagai wahana ilmu pengetahuan memegang peranan penting dalam pendidikan dalam upaya untuk meningkatkan kualitas sumber daya manusia. Mengingat pentingnya matematika sebagai ilmu dasar, maka pembelajaran matematika di berbagai jenjang pendidikan formal perlu mendapat perhatian yang serius. National Council of Teachers of Mathematics (NCTM) menetapkan kemampuan penalaran sebagai salah satu standar proses yang harus dimiliki oleh peserta didik (Wahyudi, Purwanto, \& Mulyati, 2016). Kemampuan penalaran matematis sangat diperlukan untuk mengembangkan sikap ilmiah peserta didik (Astuti, Masykur, \& Pratiwi, 2018). Kemampuan penalaran matematis merupakan cara berpikir matematis peserta didik untuk menarik kesimpulan, berdasarkan sumber yang relevan atau aturan yang telah dibuktikan kebenarannya (Lestari \& Prahmana, 2017). Penalaran matematika adalah dasar untuk mengonstruksi pengetahuan matematika (Saputri, Susanti, \& Aisyah, 2017).

Meskipun kemampuan penalaran sangat penting karena berpengaruh terhadap hasil belajar, pada kenyataannya kemampuan penalaran matematis peserta didik belum memperoleh hasil yang baik dan maksimal. Berdasarkan hasil wawancara kepada guru matematika kelas VII di UPT SMPN 3 Mattirosompe, diperoleh informasi bahwa penyebab kemampuan penalaran matematis peserta didik rendah yaitu sebagian besar peserta didik beranggapan bahwa matematika merupakan mata pelajaran yang sulit sehingga menyebabkan mereka cenderung pasif dalam proses pembelajaran. Peserta didik yang tidak ikut aktif dalam proses pembelajaran dapat menyebabkan peserta didik sulit dalam bereksplorasi, berkembang, dan kreatif terhadap ide yang mereka miliki khususnya ide matematika. Kegiatan seperti ini menyebabkan peserta didik tidak mampu mengembangkan kemampuan bernalarnya.

Salah satu usaha yang dapat dilakukan guru untuk mencapai tujuan pembelajaran adalah dengan mengembangkan variasi mengajar, baik model, metode, pendekatan maupun strategi pembelajaran sehingga dapat tercipta pembelajaran yang aktif dan menyenangkan (Hapmita, M, \& Arif, 2014). Strategi pembelajaran menurut Gerlach \& Ely dalam Mudlofir (2016) yaitu cara yang dipilih untuk penyampaian materi pelajaran dalam lingkungan pengajaran tertentu, termasuk desain, durasi dan penjelasan kegiatan yang memberikan pengalaman belajar kepada peserta didik. Strategi pangajaran yang menarik dapat membuat peserta didik semangat mengikuti pelajaran dan dapat meningkatkan kemampuan bernalar matematis mereka. Strategi yang efektif untuk meningkatan kemampuan penalaran matematis peserta didik diantaranya Strategi Pembelajaran Peningkatan Kemampuan Berpikir (SPPKB) dan Strategi Pembelajaran Ekspositori (SPE).

SPPKB merupakan strategi pembelajaran yang difokuskan pada peningkatan kemampuan penalaran peserta didik untuk menganalisis fakta atau persepsi anak sebagai sumber untuk memecahkan masalah (Puspaningtyas, 2019). Selain itu, SPPPKB menekankan keikutsertaan peserta didik secara utuh dalam pembelajaran agar peserta didik lebih terlibat dalam proses pembelajaran. Dalam penerapan SPPKB peserta didik 
tidak seharusnya sebagai objek belajar yang hanya duduk mendengarkan penjelasan guru kemudian membuat catatan untuk dihafalkan (Amri \& Ratnawuri, 2016). Tahapan SPPKB menurut Sanjaya (2009), yaitu tahap orientasi, tahap pelacakan, tahap konfrontasi, tahap inkuiri, tahap akomodasi, dan tahap transfer. Penelitian yang dilakukan oleh Velina \& Nurhasanah (2017) menyimpulkan bahwa penerapan strategi pembelajaran peningkatan kemampuan berpikir (SPPKB) memiliki pengaruh signifikan terhadap kemampuan berpikir kritis biologi peserta didik kelas XI di SMA Al-Kautsar Bandar Lampung. Selain itu, Arifin (2018) juga menyatakan bahwa terdapat peningkatan signifikan pada kemampuan kognitif peserta didik dengan penerapan SPPKB dibandingkan sebelum penerapan SPPKB.

Menurut Sanjaya (2009), SPE menekankan pada cara menyampaikan materi secara lisan dari guru kepada sekelompok peserta didik dengan tujuan peserta didik dapat mempelajari materi pelajaran secara maksimal. Menurut Djamarah dalam Sunarto, Sumarni, \& Suci (2008), SPE dilaksanakan melalui beberapa tahap, yaitu tahap pendahuluan (menyampaikan tujuan pembelajaran), tahap persiapan (mempersiapkan bahan pembelajaran secara sistematis), tahap apersepsi (memberikan uraian singkat untuk mengarahkan perhatian peserta didik terkait materi pembelajaran), tahap presentasi (menyajikan materi secara jelas), dan tahap resitasi (mengajukan pertanyaan kepada peserta didik atau meminta peserta didik menyatakan kembali konsep materi yang dijelaskan sebelumnya oleh guru). Tahap terakhir adalah pengembangan berupa penugasan. Dalam penelitian yang dilakukan oleh Rizal, Tayeb, \& Latuconsina (2016) diperoleh bahwa hasil belajar matematika peserta didik kelas VIII MTsN Ma"rang Kabupaten Pangkep dapat ditingkatkan melalui metode ekspositori berbasis kuis efektif. Berdasarkan hal tersebut, peneliti ingin membandingkan tingkat kemampuan penalaran matematis peserta didik kelas VII UPT SMPN 3 Mattirosompe kabupaten Pinrang antara penerapan Strategi Pembelajaran Peningkatan Kemampuan Berpikir (SPPKB) dan Strategi Pembelajaran Ekspositori (SPE).

\section{METODE PENELITIAN}

Jenis penelitian ini adalah quasi experiment (eksperimen semu) dengan non equivalent control group design. Penelitian ini dilakukan di UPT SMPN 3 Mattirosompe, desa Katteong, kelurahan Samaenre, kecamatan Mattirosompe, kabupaten Pinrang, provinsi Sulawesi Selatan. Populasi penelitian adalah peserta didik kelas VII UPT SMPN 3 Mattirosompe. Sampel penelitian ini adalah peserta didik kelas VII.1 sebagai kelas eksperimen 1 yang diajar menggunakan Strategi Pembelajaran Peningkatan Kemampuan Berpikir (SPPKB) dan peserta didik kelas VII.3 sebagai kelas eksperimen 2 yang diajar menggunakan Strategi Pembelajaran Ekspositori (SPE) yang dipilih dengan menggunakan teknik simple random sampling. Kelas eksperimen 1 dan eksperimen 2 masing-masing terdiri atas 28 peserta didik. Instrumen penelitian menggunakan tes kemampuan penalaran matematis dalam bentuk soal uraian. Tiap kelas eksperimen diberi pretest, perlakuan, dan posttest. Selanjutnya, data yang diperoleh dianalisis menggunakan analisis statistik deskriptif dan analisis statistik inferensial. Uji hipotesis menggunakan uji $t$ dua sampel bebas (independent sample t-test) dengan uji prasyarat, yaitu uji normalitas dan uji homogenitas. 


\section{HASIL DAN PEMBAHASAN}

1. Deskripsi Kemampuan Penalaran Matematis Peserta Didik Kelas VII UPT SMPN 3 Mattirosompe dengan Penerapan SPPKB

Data hasil tes kemampuan penalaran matematis peserta didik kelas eksperimen 1 dengan menggunakan SPPKB ditampilkan pada tabel 1.

Tabel 1. Rekapitulasi Hasil Kemampuan Penalaran pada Kelas Eksperimen 1

\begin{tabular}{ccc}
\hline \multirow{2}{*}{ Statistik } & \multicolumn{2}{c}{ Nilai Statistik Kelas VII.1 } \\
\cline { 2 - 3 } & Pretest Kelas Eksperimen 1 & Posttest Kelas Eksperimen 1 \\
\hline Jumlah Sampel & 28 & 28 \\
Nilai Terendah & 30 & 72 \\
Nilai Tertinggi & 65 & 90 \\
Rata-rata & 46,86 & 81,86 \\
\hline
\end{tabular}

Berdasarkan tabel 1, diketahui bahwa nilai terendah yang diperoleh peserta didik sebelum pembelajaran adalah 30. Namun, setelah pembelajaran dengan menggunakan SPPKB, skor tertinggi yang diperoleh peserta didik adalah 90 dan skor terendah adalah 75 . Selanjutnya, kemampuan penalaran matematis peserta didik kelas eksperimen 1 dikategorikan pada Gambar 1.

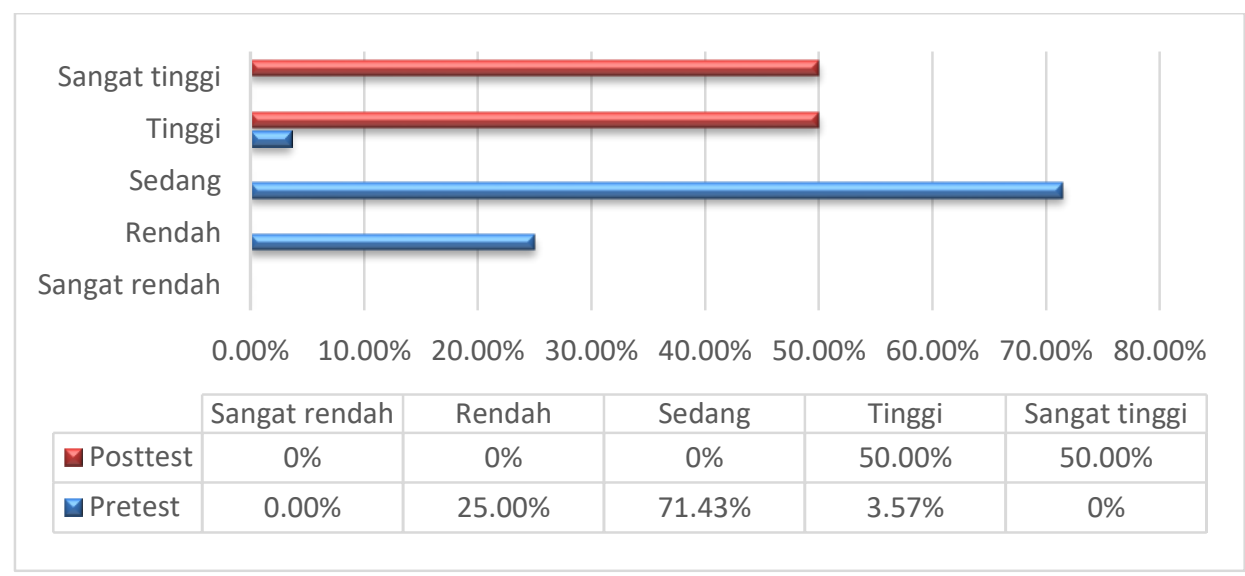

Gambar 1. Kategori Kemampuan Penalaran Matematis Peserta didik Kelas Eksperimen 1

Berdasarkan gambar 1, kemampuan penalaran matematis peserta didik kelas eksperimen 1 sebelum perlakuan dengan SPPKB berada pada kategori sedang dan rendah. Namun, setelah pembelajaran dengan menerapkan SPPKB, kemampuan penalaran matematis peserta didik berada pada kategori tinggi sebanyak $50 \%$ dan sangat tinggi sebanyak $50 \%$.

2. Deskripsi Kemampuan Penalaran Matematis Peserta didik Kelas VII UPT SMPN 3 Mattirosompe dengan Penerapan SPE

Data hasil tes kemampuan penalaran matematis peserta didik kelas eksperimen 2 dengan menggunakan SPE ditampilkan pada tabel 2. 
Tabel 2. Rekapitulasi Hasil Kemampuan Penalaran pada Kelas Eksperimen 2

\begin{tabular}{ccc}
\hline \multirow{2}{*}{ Statistik } & \multicolumn{2}{c}{ Nilai Statistik Kelas VII.3 } \\
\cline { 2 - 3 } & Pretest Kelas Eksperimen 2 & Posttest Kelas Eksperimen 2 \\
\hline Jumlah Sampel & 28 & 28 \\
Nilai Terendah & 30 & 70 \\
Nilai Tertinggi & 60 & 89 \\
Rata-rata & 44,5 & 79,34 \\
\hline
\end{tabular}

Berdasarkan tabel 2, diketahui bahwa nilai terendah yang diperoleh peserta didik sebelum pembelajaran adalah 30. Namun, setelah pembelajaran dengan menggunakan SPE, skor tertinggi yang diperoleh peserta didik adalah 89, sementara skor terendahnya adalah 70. Selanjutnya, kemampuan penalaran matematis peserta didik kelas eksperimen 2 dikategorikan pada Gambar 2.

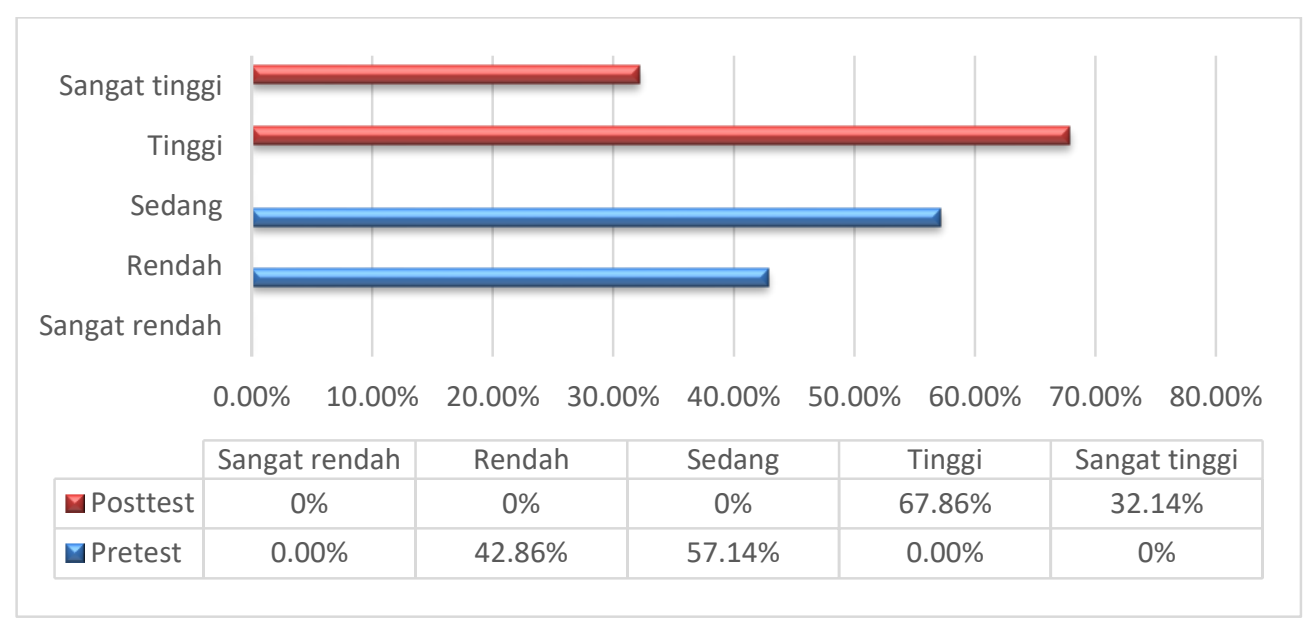

Gambar 2. Kategori Kemampuan Penalaran Matematis Peserta didik Kelas Eksperimen2

Berdasarkan gambar 2, kemampuan penalaran matematis peserta didik kelas eksperimen 2 sebelum perlakuan dengan SPE berada pada kategori sedang dan rendah. Namun, setelah pembelajaran dengan menerapkan SPE, kemampuan penalaran matematis peserta didik berada pada kategori tinggi sebesar $67,86 \%$ dan kategori sangat tinggi sebanyak $32,14 \%$.

\section{Perbandingan Kemampuan Penalaran Matematis Peserta didik antara Kelas yang Diajar dengan SPPKB dan Kelas yang Diajar dengan SPE}

Sebelum dilakukan uji hipotesis, terlebih dahulu dilakukan uji normalitas dan uji homogenitas. Berdasarkan uji normalitas data posttest kelas eksperimen 1 diperoleh $X_{\text {hitung }}^{2}=7,958$. Dalam tabel statistik, nilai $X^{2}$ dengan taraf signifikansi $\alpha=0,05$ diperoleh $X_{\text {tabel }}^{2}=11,1$, sehingga $X_{\text {hitung }}^{2}<X_{\text {tabel }}^{2}$ dengan $d k=k-1$. Jadi, dapat disimpulkan bahwa data posttest kelas eksperimen 1 setelah penerapan SPPKB berdistribusi normal. Demikian pula, uji normalitas data posttest kelas eksperimen 2 diperoleh $X_{\text {hitung }}^{2}=8,473$. Dalam tabel statistik, nilai $X^{2}$ dengan taraf signifikansi $\alpha=$ 0,05 diperoleh $X_{\text {tabel }}^{2}=11,1$, sehingga $X_{\text {hitung }}^{2}<X_{\text {tabel }}^{2}$ dengan $d k=k-1$. Jadi, dapat 
disimpulkan bahwa data posttest kelas eksperimen 2 setelah penerapan SPE juga berdistribusi normal

Selanjutnya, dilakukan uji homogenitas data posttest kelas eksperimen 1 dan kelas eksperimen 2. Berdasarkan perhitungan, diperoleh $F_{\text {hitung }}=1,88$. Nilai $F_{\text {tabel }}$ dengan $d k$ pembilang $=2-1=1$ dan $d k$ penyebut $28+28-2=54$ pada taraf signifikansi $\alpha=$ 0,05 , diperoleh $F_{\text {tabel }}=4,02$, sehingga $F_{\text {hitung }}<F_{\text {tabel }}$. Jadi, dapat disimpulkan bahwa data posttest kelas eksperimen 1 dan kelas eksperimen 2 homogen.

Uji hipotesis menggunakan uji t dua sampel bebas (independent sample t-test). Adapun hipotesis statistiknya sebagai berikut:

$$
\begin{aligned}
& H_{0}: \mu_{1}=\mu_{2} \\
& H_{1}: \mu_{1} \neq \mu_{2}
\end{aligned}
$$

Keterangan:

$H_{0}$ : tidak terdapat perbedaan rata-rata kemampuan penalaran matematis peserta didik kelas VII UPT SMPN 3 Mattirosompe antara penerapan SPPKB dengan SPE.

$H_{1}$ : terdapat perbedaan rata-rata kemampuan penalaran matematis peserta didik kelas VII UPT SMPN 3 Mattirosompe antara penerapan SPPKB dengan SPE.

Uji hipotesis menunjukkan bahwa $t_{\text {hitung }}=2,108$ dan nilai $t_{\text {tabel }}$ dengan $\alpha=0,05$ dan $\mathrm{dk}=(28+28-2)=54$ adalah 1,67. Karena $t_{\text {hitung }}>t_{\text {tabel }}$, maka disimpulkan bahwa $H_{0}$ ditolak. Hal ini berarti terdapat perbedaan rata-rata kemampuan penalaran matematis peserta didik kelas VII UPT SMPN 3 Mattirosompe kabupaten Pinrang antara kelas yang diajar dengan menerapkan SPPKB dan kelas yang diajar dengan menerapkan SPE.

Kemampuan penalaran matematis peserta didik setelah diajar dengan SPPKB mengalami peningkatan. Hal tersebut dapat dilihat dari nilai rata-rata pretest adalah 48,86 dan nilai rata-rata posttest adalah 81,86 . Hal ini dikarenakan tahapan SPPKB mampu mendukung suasana pembelajaran yang kondusif dan membuat peserta didik lebih aktif dengan mengikutsertakan peserta didik dalam keseluruhan proses pembelajaran. Pada SPPKB, peserta didik dihadapkan pada masalah yang perlu dijawab berdasarkan bukti atau pengetahuannya sebagai bahan untuk mengembangkan kemampuan berpikir dan memecahkan masalah yang disajikan oleh guru dalam proses pembelajaran, sehingga peserta didik memahami materi pembelajaran dengan lebih efektif dan memungkinkan peserta didik untuk meningkatkan hasil belajar (Waluyati, Faisal, \& Putri, 2014). SPPKB menitikberatkan pada peningkatan kemampuan berpikir peserta didik untuk menelaah fakta-fakta pengalaman peserta didik sebagai informasi untuk menyelesaikan masalah yang disajikan (Amri \& Ratnawuri, 2016).

Kemampuan penalaran matematis peserta didik setelah pembelajaran dengan SPE mengalami peningkatan. Hal tersebut dapat dilihat dari nilai rata-rata pretest adalah 44,5 dan nilai rata-rata posttest adalah 79,34. Pada penelitian ini diperoleh hasil bahwa terjadi peningkatan kemampuan penalaran matematis peserta didik yang diajar dengan menggunakan SPPKB dan SPE. Pada kedua kelas tersebut, terlihat jelas bahwa pada 
posttest kelas eksperimen 1 mengalami peningkatan yang cukup maksimal pada kategori tinggi dan sangat tinggi, sedangkan pada hasil posttest kelas eksperimen 2 terjadi penigkatan pada kategori tinggi. Jadi dapat disimpulkan bahwa terjadi peningkatan ratarata hasil kemampuan penalaran matematis peserta didik pada kelas yang diajar dengan menggunakan SPPKB dan SPE. Hal ini disebabkan strategi pembelajaran yang digunakan mampu membuat peserta didik benar-benar ikut berpartisipasi dalam pembelajaran dengan penggunaan aktivitas yang berkesinambungan, mendorong peserta didik untuk berpikir dan bernalar, sehingga pembelajaran lebih bermakna. Peserta didik tidak sekedar menghapal rumus, akan tetapi peserta didik dapat menemukan sendiri, mampu mengembangkan konsep, dapat menerapkan dalam kehidupan dan dapat mentransfer dalam bentuk baru sehingga peserta didik menjadi aktif dalam pembelajaran dan dapat mengkontruksi sendiri pengetahuan dengan melibatkan masalah dalam kehidupan seharihari. Selain jumlah pertemuan yang semakin banyak, peserta didik juga semakin aktif dalam bertanya dan menjawab pertanyaan sehingga kemampuan mengerjakan soal juga semakin meningkat.

Berdasarkan hasil pengujian hipotesis, diperoleh bahwa terdapat perbedaan ratarata kemampuan penalaran matematis peserta didik kelas VII UPT SMPN 3 Mattirosompe antara penerapan SPPKB dengan SPE. Hasil penelitian ini juga didukung oleh beberapa penelitian sebelumnya, salah satunya adalah penelitian yang dilakukan oleh Arifin (2018). Dari hasil penelitian tersebut diperoleh bahwa terdapat peningkatan hasil belajar peserta didik berdasarkan perolehan nilai peserta didik sebelum dan sesudah pembelajaran dengan menggunakan strategi pembelajaran peningkatan kemampuan berpikir.

\section{SIMPULAN}

Kemampuan penalaran matematis peserta didik kelas VII UPT SMPN 3 Mattirosompe dengan menerapkan Strategi Pembelajaran Peningkatan Kemampuan Berpikir (SPPKB) memiliki persentase sebesar 50\% pada kategori tinggi dan 50\% pada kategori sangat tinggi dengan nilai rata-rata 81,86. Kemampuan penalaran matematis peserta didik kelas VII UPT SMPN 3 Mattirosompe dengan menerapkan Strategi Pembelajaran Ekspositori (SPE) memiliki persentase sebesar 67,86\% pada kategori tinggi dan $32,14 \%$ pada kategori sangat tinggi dengan nilai rata-rata 79,34 . Selain itu, terdapat perbedaan yang signifikan antara kemampuan penalaran matematis peserta didik kelas VII UPT SMPN 3 Mattirosompe yang menggunakan Strategi Pembelajaran Peningkatan Kemampuan Berpikir (SPPKB) dan yang menggunakan Strategi Pembelajaran Ekspositori (SPE).

\section{DAFTAR PUSTAKA}

Amri, R. F., \& Ratnawuri, T. (2016). Pengaruh penggunaan strategi pembelajaran peningkatan kemampuan berpikir (SPPKB) terhadap hasil belajar kewirausahaan siswa kelas XI semester genap SMK Muhammadiyah 2 Metro T.P 2015/2016. PROMOSI Jurnal Pendidikan Ekonomi), 4(1), 46-54. https://doi.org/10.24127/ja.v4i1.475

Arifin, Z. (2018). Meningkatkan hasil belajar dengan strategi pembelajaran peningkatan kemampuan berpikir. Jurnal THEOREMS (The Original Research of Mathematics), $2(2), 42$. 
Astuti, T. P., Masykur, R., \& Pratiwi, D. D. (2018). Pengaruh model pembelajaran tandur terhadap kemampuan pemahaman konsep dan penalaran matematis peserta didik. AKSIOMA: Jurnal Program Studi Pendidikan Matematika, 7(2), 201. https://doi.org/10.24127/ajpm.v7i2.1497

Hapmita, D., M, S., \& Arif, S. (2014). Penerapan strategi pembelajaran peningkatan kemampuan berpikir (SPPKB) dalam pembelajaran IPS terpadu. PESAGI (Jurnal Pendidikan Dan Penelitian Sejarah), 2(3).

Lestari, R. M., \& Prahmana, R. C. I. (2017). Model guided inquiry, student teams achievement division, dan kemampuan penalaran matematis siswa. Beta Jurnal Tadris Matematika, 10(2), 153-165. https://doi.org/10.20414/betajtm.v10i2.119

Mudlofir, A. (2016). Desain pembelajaran inovatif. Jakarta: Rajawali Pers.

Puspaningtyas, N. A. (2019). Peningkatan higher order thinking skills (HOTS) melalui strategi pembelajaran kemampuan berpikir (SPPKB) pada pembelajaran ekonomi. Jurnal Pendidikan Dan Ekonomi, 8(2), 134-141.

Rizal M, M., Tayeb, T., \& Latuconsina, N. (2016). Efektivitas penerapan metode ekspositori berbasis kuis terhadap hasil belajar matematika siswa kelas VIII MTsN Ma'Rang Kabupaten Pangkep. MaPan, 4(2), 171-184. https://doi.org/10.24252/mapan.2016v4n2a2

Sanjaya, W. (2009). Strategi pembelajaran berorientasi standar proses pendidikan. Jakarta: Kencana.

Saputri, I., Susanti, E., \& Aisyah, N. (2017). Kemampuan Penalaran Matematis Siswa Menggunakan Pendekatan Metaphorical Thinking pada Materi Perbandingan Kelas VIII Di SMPN 1 Indralaya Utara. 3(1), 15-24.

Sunarto, W., Sumarni, W., \& Suci, E. (2008). Hasil belajar kimia siswa dengan model pembelajaran metode think-pair-share dan metode ekspositori. Jurnal Inovasi Pendidikan Kimia, 2(1), 244-249.

Velina, Y., \& Nurhasanah, W. (2017). Pengaruh strategi pembelajaran peningkatan kemampuan berpikir (SPPKB) terhadap kemampuan berpikir kritis biologi peserta didik kelas XI SMA Al-Kautsar Bandar Lampung. BIOSFER Jurnal Tadris Pendidikan Biologi, 8(2), 67-83.

Wahyudi, W., Purwanto, P., \& Mulyati, S. (2016). Penalaran matematis siswa berkemampuan tinggi dan rendah dalam menyelesaikan persamaan kuadrat. Jurnal Pendidikan: Teori, Penelitian, Dan Pengembangan, 1(7), 1287-1296.

Waluyati, S. A., Faisal, E. El, \& Putri, N. A. (2014). Pengaruh strategi pembelajaran peningkatan kemampuan berpikir (SPPKB) terhadap hasil belajar pendidikan kewarganegaraan siswa kelas XI SMAN 1 Tebing Tinggi. Bhineka Tunggal Ika: Kajian Teori Dan Praktik Pendidikan PKn, 1(2), 116-122. 